\title{
Overexpression of Glut4 Protein in Muscle Increases Basal and Insulin-stimulated Whole Body Glucose Disposal in Conscious Mice
}

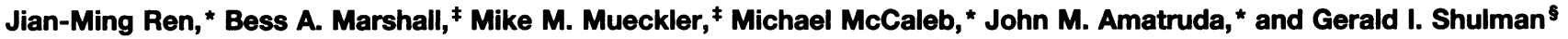 \\ *Institute for Metabolic Disorders, Miles Inc., West Haven, Connecticut 06516; ${ }^{\ddagger}$ Department of Cell Biology and Physiology, \\ Washington University, School of Medicine, St. Louis, Missouri 63110; and ${ }^{\S}$ Department of Internal Medicine, Yale University, School of \\ Medicine, New Haven, Connecticut 06520
}

\begin{abstract}
The effect of increased Glut4 protein expression in muscle and fat on the whole body glucose metabolism has been evaluated by the euglycemic hyperinsulinemic clamp technique in conscious mice. Fed and fasting plasma glucose concentrations were $172 \pm 7$ and $78 \pm 7 \mathrm{mg} / \mathrm{dl}$, respectively, in transgenic mice, and were significantly lower than that of nontransgenic littermates $(208 \pm 5 \mathrm{mg} / \mathrm{dl}$ in fed; $102 \pm 5$ $\mathrm{mg} / \mathrm{dl}$ in fasting state). Plasma lactate concentrations were higher in transgenic mice, $(6.5 \pm 0.7 \mathrm{mM}$ in the fed and $5.8 \pm 1.0 \mathrm{mM}$ in fasting state) compared with that of nontransgenic littermates $(4.7 \pm 0.3 \mathrm{mM}$ in the fed and $4.2 \pm 0.5$ $\mathrm{mM}$ in fasting state). In the fed state, the rate of whole body glucose disposal was $\mathbf{7 0 \%}$ higher in transgenic mice in the basal state, 81 and $54 \%$ higher during submaximal and maximal insulin stimulation. In the fasting state, insulinstimulated whole body glucose disposal was also higher in the transgenic mice. Hepatic glucose production after an overnight fast was $24.8 \pm 0.7 \mathrm{mg} / \mathrm{kg}$ per min in transgenic mice, and $25.4 \pm 2.7 \mathrm{mg} / \mathrm{kg}$ per min in nontransgenic mice. Our data demonstrate that overexpression of Glut4 protein in muscle increases basal as well as insulin-stimulated whole body glucose disposal. These results suggest that skeletal muscle glucose transport is rate-limiting for whole body glucose disposal and that the Glut4 protein is a potential target for pharmacological or genetic manipulation for treatment of patients with non-insulin-dependent diabetes mellitus. (J. Clin. Invest. 1995. 95:429-432.) Key words: transgenic mice $\cdot$ human Glut4 protein
\end{abstract}

\section{Introduction}

Insulin resistance is a common feature of non-insulin-dependent diabetes mellitus (NIDDM). ${ }^{1}$ Although impaired muscle glucose transport in diabetic patients has been implicated as one of the causes for insulin resistance (1-3), muscle hexokinase and glycogen synthase may also be defective in diabetic

Address correspondence to Jian-Ming Ren, Ph.D., Miles Inc., 400 Morgan Lane, West Haven, CT 06516. Phone: 203-937-2711; FAX: 203937-2686. 1994.

Received for publication 1 June 1994 and in revised form 30 August

1. Abbreviation used in this paper: NIDDM, non-insulin-dependent diabetes mellitus.

J. Clin. Invest.

(c) The American Society for Clinical Investigation, Inc.

0021-9738/95/01/0429/04 \$2.00

Volume 95, January 1995, 429-432 patients, both of which could cause insulin resistance $(1,4,5)$. Muscle cells express two glucose transporter isoforms, Glut1 and Glut4 (6-8). Glut1 resides constitutively in the plasma membrane and is believed to be responsible for basal glucose transport in muscle, although Glut4 may also contribute (7). In striated muscle, the major glucose transporter is the Glut4 isoform (9), which undergoes translocation to the plasma membrane in response to insulin $(10,11)$. In type II diabetes, the muscle Glut4 protein level is not decreased compared with that of nondiabetic subjects (12), but insulin-stimulated glucose utilization is markedly reduced $(1,3)$. Whether the translocation process of Glut4 to the plasma membrane in NIDDM patients is impaired remains to be determined. There is evidence that an increased total muscle Glut 4 content induced by exercise is associated with the increase in insulin-stimulated translocation of Glut4 in rat skeletal muscle (13).

In a previous study, we demonstrated that basal muscle glycogen deposition and glycolysis were markedly increased in transgenic mice overexpressing Glut 1 protein in skeletal muscle (14). Insulin at a supermaximal concentration was ineffective in stimulating muscle glucose transport (15), muscle glycogen synthase and glycogen deposition in isolated muscle strips of transgenic mice (Ren, J. M., unpublished results). Recently, Marshall \& Mueckler reported that overexpression of Glut4, but not Glut1 increased insulin responsiveness as measured by the glucose infusion rate in anesthetized mice after an overnight fast (16). The basal glucose disposal, insulin sensitivity, and hepatic glucose production were not determined in that study. The present study was undertaken to investigate the effect of muscle and fat Glut4 protein overexpression on basal and insulin-stimulated whole body glucose disposal in vivo using the euglycemic hyperinsulinemic clamp in combination with tracer technique in conscious mice. A line of transgenic mice expressing high levels of the human Glut4 protein was generated (17). Plasma glucose concentrations are markedly reduced in transgenic mice in both the fed and fasting states when compared with those of nontransgenic littermates. Our data show that in the fed state, the basal rate of glucose disposal is increased in transgenic mice, while insulin-stimulated glucose disposal was also higher in transgenic mice in both the fed and fasting states.

\section{Methods}

Animals. The construction of transgenic mice carrying the human Glut4 glucose transporter genomic DNA (hGLUT4-11.5) has been described previously (18). All animals used for experiments were males and the littermates were obtained from the breeding of a single line of Glut4 heterozygous overexpressing mice (hGLUT4-11.5B) (18) with nontransgenic C57BL/6xSJL F2 mice. Animals were housed in a room maintained at $23^{\circ} \mathrm{C}$ with a fixed 12-h light/dark cycle and given free access to chow (Ralston Purina Co., St. Louis, MO) and water ad lib. $3 \mathrm{~d}$ before the in vivo experiments, mice were anesthetized with an 
intraperitoneal injection of ketamine and xylazine $(25 \mathrm{mg} / 100 \mathrm{~g}$ of body wt) and a catheter was inserted in the left jugular vein. The venous catheter was advanced to the level of the right atrium.

Euglycemic clamp study. All experiments were performed in awake mice using a two-step euglycemic clamp technique as described in rats (19) and adapted for mice. Animals were either fed ad lib. or fasted for $18 \mathrm{~h}$ before the experiment. [ $\left.3-{ }^{3} \mathrm{H}\right]$ glucose (New England Nuclear, Boston, MA) was infused throughout the clamp experiment to determine the glucose turnover rate. A priming dose of $2.5 \mu \mathrm{Ci}$ in $100 \mu \mathrm{l}$ of saline $(0.9 \%)$ was infused followed by continuous infusion at a rate of 0.08 $\mu \mathrm{Ci} / \mathrm{min}(3 \mu \mathrm{l} / \mathrm{min})$ for $5 \mathrm{~h}$. For the basal glucose turnover rate measurements, blood samples were collected at 70, 80, and $90 \mathrm{~min}$ after the initiation of $\left[3-{ }^{3} \mathrm{H}\right]$ glucose infusion. Rat insulin was infused at a constant rate of $2.5 \mathrm{mU} / \mathrm{kg}$ per min for $90 \mathrm{~min}$, while $25 \%$ dextrose was infused by a variable infusion pump (Harvard Apparatus Inc., South Natick, MA). Blood samples (25 $\mu$ l) were collected from the tail-tip at 10-min intervals for determination of plasma glucose. Plasma glucose concentration was maintained at $160 \mathrm{mg} / \mathrm{dl}$ during the insulin infusion. Blood samples $(20 \mu \mathrm{l})$ were also obtained during the last $30 \mathrm{~min}$ of insulin infusion for $\left[3-{ }^{3} \mathrm{H}\right]$ glucose specific activity measurements, during which the blood glucose concentration was in a steady state. Thereafter, insulin infusion rate was increased to $20 \mathrm{mU} / \mathrm{kg}$ per min for 90 $\mathrm{min}$. The total volume of blood withdrawn was $0.5 \mathrm{ml}$ per mouse. To prevent anemia, a $1-\mathrm{ml}$ heparinized saline $(10 \mathrm{U} / \mathrm{ml})$ solution containing $0.5 \mathrm{ml}$ fresh blood (obtained by heart puncture from a donor mouse) was infused together with insulin. Parallel experiments using the same animals were performed under identical conditions to obtain enough blood for plasma insulin measurement before and during each step of the clamp. The rate of glucose appearance or glucose turnover rate was calculated under steady state conditions by dividing the $\left[3-{ }^{3} \mathrm{H}\right]$ glucose infusion rate (disintegration per minute $/ \mathrm{kg}$ per $\mathrm{min}$ ) by the mean plasma glucose specific activity (disintegration per minute/mg glucose) obtained during the last $30 \mathrm{~min}$ of each step of the clamp. The rate of hepatic glucose production was calculated by subtracting the glucose infusion rate from the glucose turnover rate.

Analytical procedures. Plasma glucose was measured by the glucose oxidase method (Glucose Analyzer II; Beckman Instruments, Inc., Fullerton, $\mathrm{CA}$ ) and plasma glucagon and insulin by double-antibody radioimmunoassay using rat and human standards, respectively. For $\left[3-{ }^{3} \mathrm{H}\right]-$ glucose measurements, plasma samples were extracted with $10 \%$ TCA to precipitate proteins. The supernatants were evaporated to dryness to eliminate tritiated water before being counted on a $\beta$ scintillation counter for $\left[3-{ }^{3} \mathrm{H}\right]$ glucose radioactivity. Plasma lactate and $\beta$-hydroxybutyrate concentrations were determined using an automated chemistry analyzer (Cobas Mira; Roche Diagnostics Nutley, NJ) and diagnostic, reagent kits (Sigma Chemical Co., St. Louis, MO).

Statistical analysis. All values are presented as the means \pm standard error. Student's $t$ test was performed for comparisons between two groups. Significant difference was set at $P<0.05$.

\section{Results}

Characteristics of the animals. The mean body wt of the transgenic mice was not different from that of nontransgenic littermates ( $25 \pm 2$ vs. $27 \pm 1 \mathrm{~g}$ ) in the fed state indicating normal growth of the transgenic mice. However, the mean plasma glucose concentrations in the fed and fasting states were significantly lower in the transgenic mice compared with the control mice (Table I). The fasting plasma insulin concentration was also lower in transgenic mice (Table II). Plasma lactate and $\beta$-OH-butyrate concentrations were increased while glucagon levels were unchanged in the transgenic mice (Table I).

Whole body glucose disposal in fed and fasted mice. In the fed state, the basal glucose disposal rate was $70 \%$ higher in the transgenic than in the nontransgenic mice (Fig. 1). Insulin at the infusion rate of $2.5 \mathrm{mU} / \mathrm{kg}$ per min did not stimulate the rate of whole body glucose disposal in either transgenic or
Table I. Metabolic Characteristics of Male Glut4 Transgenic Mice and Their Nontransgenic Littermates

\begin{tabular}{lcclll}
\hline & \multicolumn{2}{c}{ Fed } & & \multicolumn{2}{c}{ Fasted } \\
\cline { 2 - 3 } \cline { 5 - 6 } \cline { 5 - 6 } & Control & Transgenic & & Control & Transgenic \\
\hline Glucose, $\mathrm{mg} / \mathrm{dl}$ & $208 \pm 5$ & $172 \pm 7^{*}$ & & $102 \pm 5^{\ddagger}$ & $78 \pm 7^{* \ddagger}$ \\
Lactate, $\mathrm{mM}$ & $4.7 \pm 0.3$ & $6.5 \pm 0.7^{*}$ & & $4.2 \pm 0.5$ & $5.8 \pm 1.0^{*}$ \\
$\beta$-OH-Butyrate, $\mathrm{mM}$ & $0.4 \pm 0.1$ & $0.7 \pm 0.1^{*}$ & & $1.3 \pm 0.1^{\ddagger}$ & $3.4 \pm 0.2^{* \ddagger}$ \\
Glucagon, $\mathrm{pg} / \mathrm{ml}$ & $209 \pm 4$ & $216 \pm 6$ & & $219 \pm 11$ & $235 \pm 18$
\end{tabular}

5-7-wk-old mice were fed ad lib. or were fasted for $18 \mathrm{~h}$ before being bled via the retro-orbital sinus using a heparinized capillary tube. Plasma metabolite and hormone levels were then measured as described in Methods. Values represent the mean \pm standard error for three to seven animals per group. Significant differences are indicated as $* P<0.05$ for comparison between control and transgenic mice; ${ }^{\ddagger} P<0.05$ for comparison between fed and fasted mice.

nontransgenic mice (Fig. 1). At the high infusion rate $(20 \mathrm{mU} /$ $\mathrm{kg}$ per $\mathrm{min}$ ), the rate of whole body glucose disposal increased twofold reaching $148.5 \pm 10.1 \mathrm{mg} / \mathrm{kg}$ per min in transgenic mice, which was $54 \%$ higher $(P<0.05)$ than that in the control mice $(96.2 \pm 13.3 \mathrm{mg} / \mathrm{kg}$ per $\mathrm{min}$ ) (Fig. 1). In the fasting state, the basal glucose disposal rate was not different between control and transgenic mice (Fig. 1). When insulin was infused at the rate of $2.5 \mathrm{mU} / \mathrm{kg}$ per min, the rate of whole body glucose disposal increased $100 \%$ in transgenic and $61 \%$ in the control mice, respectively (Fig. 1). A further increase in whole body glucose disposal was noted at insulin infusion rate of $20 \mathrm{mU} /$ $\mathrm{kg}$ per min, reaching $82.5 \pm 3.7 \mathrm{mg} / \mathrm{kg}$ per $\mathrm{min}$ in the transgenic and $52.4 \pm 1.8 \mathrm{mg} / \mathrm{kg}$ per $\mathrm{min}$ in the control mice.

Splanchnic glucose production in fed and overnight fasted mice. In the fed state, the rate of glucose appearance was $80 \%$ higher in transgenic than nontransgenic mice (Fig. 2). Insulin, at the infusion rate of $2.5 \mathrm{mU} / \mathrm{kg}$ per min, suppressed endogenous glucose production $42 \%$ in control and $71 \%$ in transgenic mice. At an infusion rate of $20 \mathrm{mU} / \mathrm{kg}$ per min, the rate of glucose production decreased to nondetectable levels in the control mice and to $12 \%$ of the initial rate in the transgenic mice (Fig. 2). In the fasting state, the rate of glucose appearance was not different between transgenic and control mice in the basal state (Fig. 2). Insulin at the infusion rate of 2.5 and 20 $\mathrm{mU} / \mathrm{kg}$ per min suppressed liver glucose production completely in both transgenic and control mice (Fig. 2).

Glucose infusion rates during the euglycemic hyperinsulinemic clamps. In the fed state, a submaximal dose of insulin $(105 \mu \mathrm{U} / \mathrm{ml})$ resulted in a threefold higher glucose infusion rate in the transgenic mice than the nontransgenic littermates (Table II) when plasma glucose concentration was kept constant. At the maximal insulin concentration, glucose infusion rate increased and was $36 \%$ higher in the transgenic mice than in the control mice (Table II). In the fasting state, glucose infusion rate was not different between the transgenic and control mice at the submaximal insulin concentration. At the maximal insulin concentration, the glucose infusion rate was $52 \%$ higher in the transgenic mice than the control mice, which was essentially identical to the rate of glucose disappearance in both the transgenic and nontransgenic mice (Table II).

\section{Discussion}

An important finding of the present study is that the basal glucose disposal rate in the fed state was $70 \%$ higher in the Glut 4 
Table II. Glucose Infusion Rates and Plasma Insulin Concentrations during the Two-Step Euglycemic Hyperinsulinemic Clamp Studies in Fed and Overnight Fasted Transgenic and Nontransgenic Mice

\begin{tabular}{|c|c|c|c|c|}
\hline & \multicolumn{2}{|c|}{ Fed } & \multicolumn{2}{|c|}{ Fasted } \\
\hline & Control & Transgenic & Control & Transgenic \\
\hline \multicolumn{5}{|c|}{ Insulin concentration $(\mu \mathrm{U} / \mathrm{ml})$} \\
\hline Basal & $25 \pm 3$ & $26 \pm 1$ & $17 \pm 3$ & $13 \pm 2$ \\
\hline Insulin I & $105 \pm 9$ & $105 \pm 11$ & $87 \pm 23$ & $68 \pm 22$ \\
\hline Insulin II & $1,039 \pm 111$ & $1,096 \pm 118$ & $744 \pm 334$ & $801 \pm 544$ \\
\hline \multicolumn{5}{|c|}{ Glucose infusion rate $(\mathrm{mg} / \mathrm{kg}$ per $\mathrm{min})$} \\
\hline Basal & 0 & 0 & 0 & 0 \\
\hline Insulin I & $20.5 \pm 5$ & $62.1 \pm 3.2^{*}$ & $40.5 \pm 2.1$ & $48.9 \pm 4.3$ \\
\hline Insulin II & $96.6 \pm 14.7$ & $131.3 \pm 10.2^{*}$ & $55.7 \pm 3.4$ & $84.5 \pm 4.0^{*}$ \\
\hline
\end{tabular}

7-9-week-old mice were fed ad lib. or were fasted for $18 \mathrm{~h}$ before being studied. Blood was collected via the tail vein, and plasma insulin was measured as described in Methods. Values represent the mean \pm standard error for $4-10$ animals per group. Insulin I: Insulin was infused at the rate of $2.5 \mathrm{mU} / \mathrm{kg}$ per min. Insulin II: Insulin was infused at the rate of $20 \mathrm{mU} / \mathrm{kg}$ per min. ${ }^{*} P<0.05$.

transgenic mice than that of nontransgenic littermates. This finding demonstrates that overexpression of Glut4 protein is sufficient to bring about an increase in whole body glucose utilization. Although the majority of the Glut4 transporters are retained in the intracellular compartments (7), an increased number of Glut 4 transporter has also been found in the plasma membrane when Glut4 is overexpressed in adipose tissue (17, $20)$. There is no available information in the literature showing the redistribution of muscle Glut4 protein in transgenic mice expressing high level of Glut4 in skeletal muscle. However, basal glucose transport activity of muscles isolated from these mice was increased $50 \%$ (21), suggesting that the Glut4 transporter numbers are increased in the plasma membrane of the transgenic mice. Since glucose transport has been shown to be rate-limiting for glycogen deposition and glycolysis in Glut1 transgenic mice (14), the cellular mechanism responsible for the increased whole body glucose utilization in Glut4 transgenic mice is likely to be due to the increase in glucose transport activity in muscle. These results indicate that the basal activities

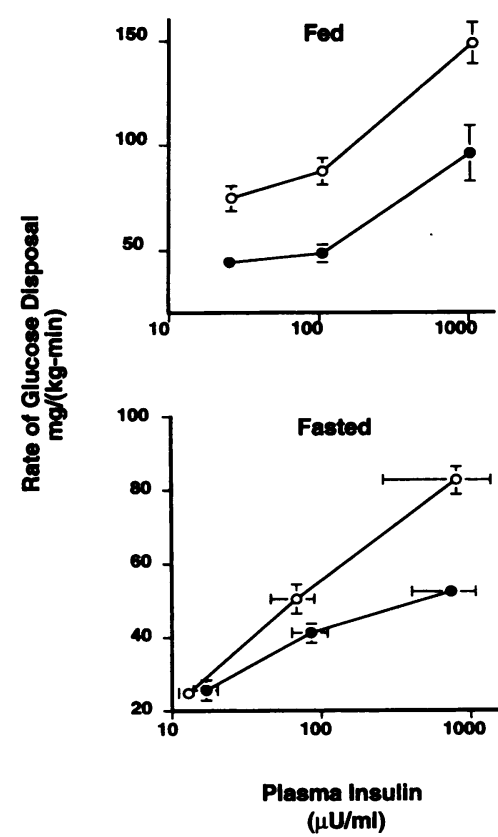

Figure 1. Effect of increasing plasma insulin concentrations on peripheral glucose disposal in fed (top) and in overnight fasted (bottom) mice. Values represent the mean $\pm S E$ from five to seven animals per group and are expressed as milligrams per kilogram per minute. The rate of glucose disposal increased significantly $(P$ $<0.05$ ) at both insulin infusion rates in fasted state. In fed state, glucose disposal rate increased significantly $(P<0.05)$ only at the high insulin infusion ( $20 \mathrm{mU} / \mathrm{kg}$ per $\mathrm{min}) . \circ$, Transgenic mice; $\bullet$, control mice. of muscle hexokinase and glycogen synthase are sufficiently high to accommodate a substantial increase in the glucose transport rate in skeletal muscle of Glut4 transgenic mice. This implies that genetic or pharmacological manipulation that would increase the level of Glut4 expression in muscles of NIDDM may provide an effective treatment for lowering blood glucose, especially in view of recent data suggesting defects in glucose transport may be responsible for decreased rates of muscle glycogen synthesis in NIDDM patients $(1,3)$.

In addition to the increase in the basal rate of glucose disposal, Glut4 transgenic mice also show an improvement of insulin-stimulated glucose disposal. This is in contrast to the Glut 1 transgenic mice, in which skeletal muscle is unresponsive to insulin's action on glucose transport, glycogen deposition and glycogen synthase $(14,16)$.

Whole body glucose homeostasis is maintained by the balance between hepatic glucose production and peripheral glucose utilization. When peripheral glucose utilization increases, blood

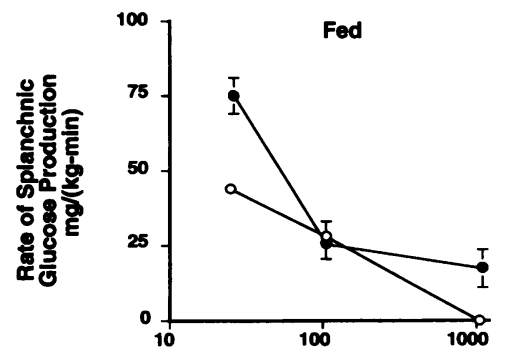

Figure 2. Effect of increasing plasma insulin concentrations on the rate of splanchnic glucose production in fed (top) and the rate of hepatic glucose production in overnight fasted (bottom)

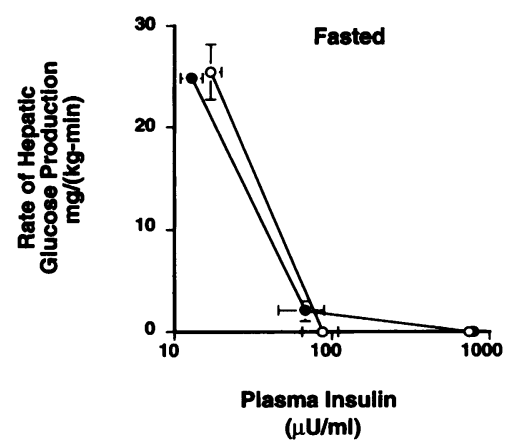
mice. Values represent the mean $\pm S E$ from five to seven animals per group and are expressed as milligram per kilogram per minute. The rate of glucose production decreased significantly $(P$ $<0.05)$ at both low (2.5 $\mathrm{mU} / \mathrm{kg}$ per $\mathrm{min}$ ) and high ( $20 \mathrm{mU} / \mathrm{kg}$ per $\mathrm{min}$ ) insulin infusion. $\bigcirc$, Control mice; •, transgenic mice. 
glucose concentration will decrease unless the liver can produce more glucose through increased glycogenolysis and/or gluconeogenesis. An increase in the availability of liver gluconeogenic precursors, such as lactate, has been shown to increase liver glucose production (22). In our studies, the rate of glucose appearance was $70 \%$ higher in the transgenic mice than in the control animals in the fed state. This finding suggests that the increase in muscle glucose transport from the Glut4 transgenic mice increases muscle glycolysis. As a result, plasma lactate concentration increases, which results in an increase in liver glucose production. Alternatively, part of the difference in the rate of glucose appearance between transgenic and nontransgenic mice may reflect a higher glucose absorption from gut and intestine of the transgenic mice. However, insulin suppressed the rate of hepatic glucose production in transgenic mice to the same rate of nontransgenic mice during low insulin infusion. These data suggest that the increased gastrointestinal glucose absorption in transgenic mice can account for only a small proportion of the high rate of glucose appearance, since insulin inhibits hepatic glucose production, but not gastrointestinal glucose absorption. We, therefore, hypothesize that the marked increase of the basal glucose production of transgenic mice in the fed state is due, at least in part, to the increase in muscle glucose transport activity.

In the fasting state, the liver is the main source of glucose production. As liver glycogen becomes depleted, the plasma glucose concentration decreases and the plasma free fatty acid level rises. These changes will cause a reduction in muscle glucose utilization (23). During fasting, the rate of hepatic glucose production in transgenic mice did not differ from that of control mice, although transgenic mice have higher Glut4 protein expression. This indicates that in the fasting state, the basal glucose utilization in muscle is not different in transgenic and control mice. The reasons that the glucose disposal rate was not higher in the transgenic mice even though there was more Glut 4 protein in the muscle may be twofold: (a) plasma insulin and glucose concentrations were significantly lower in transgenic mice resulting in a lower glucose influx into muscle cells; (b) plasma free fatty acid and triglyceride levels were higher, causing inhibition of glucose utilization in muscle as shown previously (23).

In summary, we examined rates of whole body glucose metabolism in conscious transgenic mice overexpressing Glut 4 transporter protein using the euglycemic hyperinsulinemic clamp technique. We found that by increasing Glut4 protein content in skeletal muscle, both basal and insulin-stimulated whole body glucose disposal was increased. We concluded that: (a) basal activities of muscle hexokinase and glycogen synthase are sufficiently high to keep up with the increased flux generated by increased glucose transport activity and (b) in contrast to mice who have overexpressed Glut1 protein in muscle, increased expression of Glut4 results in increased insulin responsiveness of muscle tissue. This suggests that Glut 4 protein is a potential target for therapeutic manipulation for treatment of patients with NIDDM.

\section{Acknowledgments}

The authors thank Dr. Jeff Pessin for providing the Glut4 transgenic mouse line, and Jennifer Otis for her excellent technical assistance.
This work was supported in part by the National Institutes of Health grants DK-38495 (to Dr. Mueckler) and DK-40936 (to Dr. Shulman), and John Henry \& Bernadine Foster Foundation grant (to Dr. Marshall).

\section{References}

1. Rothman, D. L., R. G. Shulman, and G. I. Shulman. $1992 .{ }^{31} \mathrm{P}$ nuclear magnetic resonance measurements of muscle glucose-6-phosphate. J. Clin. Invest. 89:1069-1075.

2. Yki-Jarvinen, H., K. Sahlin, J. M. Ren, and V. A. Koivisto. 1990. Localization of rate-limiting defect for glucose disposal in skeletal muscle of insulinresistant type I diabetic patients. Diabetes. 39:157-167.

3. Bonadonna, R. C., S. Del Prato, M. P. Saccomani, E. Bonora, G. Gulli, E. Ferrannini, D. Bier, C. Cobelli, and R. A. DeFronzo. 1993. Transmembrane glucose transport in skeletal muscle of patients with non-insulin-dependent diabetes. J. Clin. Invest. 92:486-494.

4. Damsbo, P., A. Vaag, O. Hother-Nielsen, and H. Beck-Nielsen. 1991 Reduced glycogen synthase activity in skeletal muscle from obese patients with and without type 2 (non-insulin-dependent) diabetes mellitus. Diabetologia. 34:239-245.

5. Eriksson, J., A. Franssila-Kallunki, A. Ekstrand, C. Saloranta, E. Widen, C. Schalin, and L. Groop. 1989. Early metabolic defects in persons at increased risk for non-insulin-dependent diabetes mellitus. N. Engl. J. Med. 321:337-343.

6. Burant, C. F., W. I. Sivitz, H. Fukumoto, T. Kayano, S. Nagamatsu, S. Seino, J. E. Pessin, and G. I. Bell. 1991. Mammalian glucose transporter: structure and molecular regulation. Recent Prog. Horm. Res. 47:349-387.

7. Mueckler, M. M. 1990. Family of glucose-transporter genes. Diabetes. 39:6-11.

8. Devaskar, S. U., and M. M. Mueckler. 1992. The mammalian glucose transporters. Pediatr. Res. 31:1-13.

9. James, D. E., M. Strube, and M. M. Mueckler. 1989. Molecular cloning and characterization of an insulin-regulatable glucose transporter. Nature (Lond.) 338:83-87.

10. Douen, A. G., T. Ramlal, A. Klip, D. A. Young, G. D. Cartee, and J. O. Holloszy. 1989. Exercise-induced increase in glucose transporters in plasma membranes of rat skeletal muscle. Endocrinology. 124:449-454.

11. Hirshman, M. F., L. J. Goodyear, L. J. Wardzala, E. D. Horton, and E. S Horton. 1990. Identification of an intracellular pool of glucose transporters from basal and insulin-stimulated rat skeletal muscle. J. Biol. Chem. 265:987-991.

12. Pederson, O., J. F. Bak, P. H. Andersen, S. Lund, D. E. Moller, J. S. Flier, and B. B. Kahn. 1990. Evidence against altered expression of Glut1 or Glut4 in skeletal muscle of patients with obesity or NIDDM. Diabetes. 39:865-870.

13. Ren, J. M., C. F. Semenkovich, E. A. Gulve, J. Gao, and J. O. Holloszy. 1994. Exercise induces rapid increases in Glut4 expression, glucose transport capacity, and insulin-stimulated glycogen storage in muscle. J. Biol. Chem. 269:14396-14401.

14. Ren, J. M., B. A. Marshall, E. A. Gulve, J. Gao, D. W. Johnson, J. O. Holloszy, and M. M. Mueckler. 1993. Evidence from transgenic mice that glucose transport is rate-limiting for glycogen deposition and glycolysis in skeletal muscle. J. Biol. Chem. 268:16113-16115.

15. Gulve, E. A., J. M. Ren, B. A. Marshall, J. Gao, P. A. Hansen, J. O Holloszy, and M. Mueckler. 1994. Glucose transport activity in skeletal muscles from transgenic mice overexpressing Glut1. J. Biol. Chem. 269:18366-18370.

16. Marshall, B. A., and M. Mueckler. 1994. Glut4 enhances insulin responsiveness and Glut 1 causes insulin resistance in mice overexpressing glucose transporters. Am. J. Physiol. In press.

17. Liu, M. L., M. Gibbs, S. C. McCoid, A. J. Milici, H. A. Stukenbrok, R. K McPherson, J. L. Treadway, and J. E. Pessin. 1993. Transgenic mice expressing the human Glut4/muscle-fat facilitative glucose transporter protein exhibit efficient glycemic control. Proc. Natl. Acad. Sci. USA. 90:11346-11350.

18. Olson, A. L., M. L. Liu, W. S. Moye-Rowley, J. B. Buse, G. I. Bell, and J. E. Pessin. 1993. Hormonal/metabolic regulation of the human Glut4/musclefat facilitative glucose transporter gene in transgenic mice. J. Biol. Chem. 268:9839-9846.

19. Rossetti, L. D., D. Smith, G. I. Shulman, D. Papachristou, and R. A. DeFronzo. 1987. Correction of hyperglycemia with phlorizin normalizes tissue sensitivity to insulin in diabetic rats. J. Clin. Invest. 79:1510-1515.

20. Shepherd, P. R., L. Gnudi, E. Tozzo, H. Yang, F. Leach, and B. B. Kahn 1993. Adipose cell hyperplasia and enhanced glucose disposal in transgenic mice overexpressing GLUT4 selectively in adipose tissue. J. Biol. Chem. 268:2224322246.

21. Hansen, P., E. A. Gulve, and J. O. Holloszy. 1994. Increased glucose transport activity in skeletal muscle of transgenic mice overexpressing Glut4. Diabetes (Suppl.) 43:124. (Abstr.)

22. Bailey, C. J. 1992. Biguanides and NIDDM. Diabetes Care. 15:755-772.

23. Randle, P. J., P. B. Garland, C. N. Hales, and E. A. Newsholme. 1963. The glucose fatty acid cycle. Lancet. i:785-789. 